Available Online : https://proceeding.researchsynergypress.com/index.php/cset/index

RSF Conference Series: Engineering and Technology

ISSN 2809-6843 (Online) | 2809-6878 (Print)

Volume 1 Number 1 (2021): 527-534

\title{
Effect of Sodium Hydroxide Concentration on Production of Activated Carbon from Cassava Peel
}

\author{
Mitha Puspitasari ${ }^{1}$, Wibiana Wulan Nandari ${ }^{2}$, Sri Wahyuni Santi $\mathbf{R}^{\mathbf{3}}$ \\ 1,2,3 Chemical Engineering Department, UPN “Veteran” Yogyakarta, Indonesia
}

\begin{abstract}
Cassava is a staple crop that can grow in Indonesia throughout the year and has a high adaptability to various soil conditions. Cassava or cassava can be processed into various food industries such the high carbon content of cassava peel makes it can be used as raw material for the manufacture of activated carbonas tapioca flour, fermentation industry, and other basic industries. Activated carbon is made by chemical activation of an alkaline solution. The results of the study produced activated carbon with a moisture content of $9.3406 \%$, ash content of $6.5907 \%$, iodine number $781,7656 \mathrm{mg} / \mathrm{g}$. The results of the activated carbon have met the quality standard of SNI 06-3730-1995
\end{abstract}

Keywords: Cassava, Activated Carbon, Chemical Activation

This is an open access article under the CC-BY-NC license

\section{INTRODUCTION}

According to the Central Statistics Agency, until 2020, data on imports of activated carbon in Indonesia continues to increase from the previous year. This is an opportunity for researchers to conduct research on the manufacture of activated carbon. One of the requirements for a material to be used as raw material for activated carbon is that it contains carbon.

The rapid industry that processes cassava makes more and more cassava peel waste. The waste has not been treated much and is directly discharged into the environment. This of course is very detrimental to society. Cassava peel contains carbon elements that can be used as activated carbon. For this reason, in this study, optimization of the right chemical activation conditions was carried out, in order to produce activated carbon according to SNI standardsTherefore, this research will utilize cassava peel waste that is no longer used, as a raw material for making activated carbon using an activator in the form of $\mathrm{NaOH}$ because it is easy to obtain. In addition, in this study, the water content, ash content, and iodine number of activated carbon will also be measured and reviewed based on the SNI of activated carbon.

\section{LITERATURE REVIEW}

Activated carbon is a material that has wide use in various fields, one of which is adsorbent (Bhatnagar et al., 2013). Activated carbon can also be defined as a porous carbon material with a large surface area so it is widely used for various applications. Activated carbon can be synthesized from anthracite or bituminous coal, but the use of biomass as raw material for activated carbon is being investigated. In general, the manufacture of activated carbon consists of carbonization and activation physically or chemically. (Kristianto, 2017).

The main stages in the manufacture of activated carbon are the carbonization process and the activation process. Volatile components will easily evaporate and carbon will form a porous structure during the carbonization process. The formation of closed pores and an increase in pore size occurs during the activation process (Dewi et al, 2017).

Corresponding author:

mitha.puspitasari@upnyk.ac.id; wibianawulan@upnyk.ac.id; sriwahyuni.sr@upnyk..ac.id 
Carbon that has not been activated can not be used because the pore structure is not developed. The adsorption ability of activated carbon depends on the characteristics of the carbon formed, such as: surface area, pore size distribution, functional groups on the surface, ash content, iodine number, water content and also depends on molecular weight, polarity, pKa, and molecular size (Sembiring and Sinaga, 2003)

In general, the process of making activated carbon consists of three stages, namely:

Dehydration

In the dehydration process, the water content in the raw material is removed by heating it in the oven so that the water evaporates. Carbon decomposes at a temperature of about $275 \mathrm{oC}$ and forms tar, methanol, phenol, and others. (Cerny, 1970).

\section{Carbonization}

Carbonization is a process in which the elements oxygen and hydrogen are removed from carbon and will produce a carbon skeleton that has a certain structure. Hesseler argues that in order to produce charcoal suitable for activated carbon, the carbonization is carried out at temperatures in excess of $400^{\circ} \mathrm{C}$ but it also depends on the base material and the method used for activation. Smisek and Cerny, explained that when carbonization occurs in several stages which include the removal of water or dehydration, the change of organic matter into carbon elements and decomposition of tar so that the carbon pores become larger. The product from the carbonization process has a small adsorption capacity. This is due to the low temperature carbonization process, some of the tar produced is in the pores and surfaces, resulting in blocked adsorption. The carbonized product can be activated by removing the tar product by heating in an inert gas stream, or by extraction using a suitable solvent such as selenium oxide, or by a chemical reaction. Activated carbon with high adsorption power can be produced by the activation process of raw materials that have been carbonized at high temperatures (Hassler, 1951).

\section{Activation}

One way to increase the surface area of the carbon pores is to break the bonds between hydrogen and carbon. Efforts to increase the carbon surface area or carbon activation can be done physically and chemically. The activation process causes the carbon surface area to become larger so that activated carbon has a higher adsorption capacity (Sembiring, 2003). The product of carbonization cannot be applied as an adsorbent (because the shaft structure is not developed) without additional activation. The basis of the activation method consists of treatment with an oxidizing gas at elevated temperatures. The activation process produces carbon oxides that are scattered on the carbon surface due to the reaction between carbon and oxidizing agents (Kinoshita, 1988).

The activation process aims to increase the pore volume, expand the pore surface, and add new pores. Activated carbon is burned during the activation process so that it can remove volatile substances in the pyrolysis product. Activated carbon can be activated in two ways, namely chemical activation and physical activation (Kinoshita, 1988).

\section{Chemical Activation}

Chemical activation is the process of breaking the carbon chain from organic compounds by using chemicals (Sembiring, 2003). Chemical activation usually uses activating ingredients such as calcium chloride $(\mathrm{CaCl} 2)$, magnesium chloride $(\mathrm{MgCl} 2)$, zinc chloride $(\mathrm{ZnCl} 2)$, sodium hydroxide $(\mathrm{NaOH})$, sodium carbonate $(\mathrm{Na} 2 \mathrm{CO} 3)$ and sodium chloride $(\mathrm{NaCl})$. In addition to mineral salts, usually used are various organic acids and bases such as sulfuric acid (H2SO4), 
hydrochloric acid ( $\mathrm{HCl})$, hypochlorous acid (H3PO4), potassium hydroxide (KOH), and sodium hydroxide $(\mathrm{NaOH})$.

The disadvantage of using mineral materials as activator lies in the washing process of the materials

\section{Physical Activation}

Physical activation is the breaking of carbon bonds in the presence of heat, steam and carbon dioxide (Sembiring, 2003). Physical activation methods include water vapor, carbon dioxide gas, oxygen, and nitrogen. The function of the gas is to expand the surface of the activated carbon because the cavity structure expands, removing volatile substances, and also other impurities in the activated carbon (Swiatkowski, 1998).

\section{RESEARCH METHOD \\ Material}

Prepare cassava peels that have been cleaned and cut into small pieces. Weigh the initial weight of the cassava peel, then dry the cassava peel under the sun and then weigh it again and then bake it in an oven at $100^{\circ} \mathrm{C}$ until the weight of the cassava peel is constant.

\section{Methods}

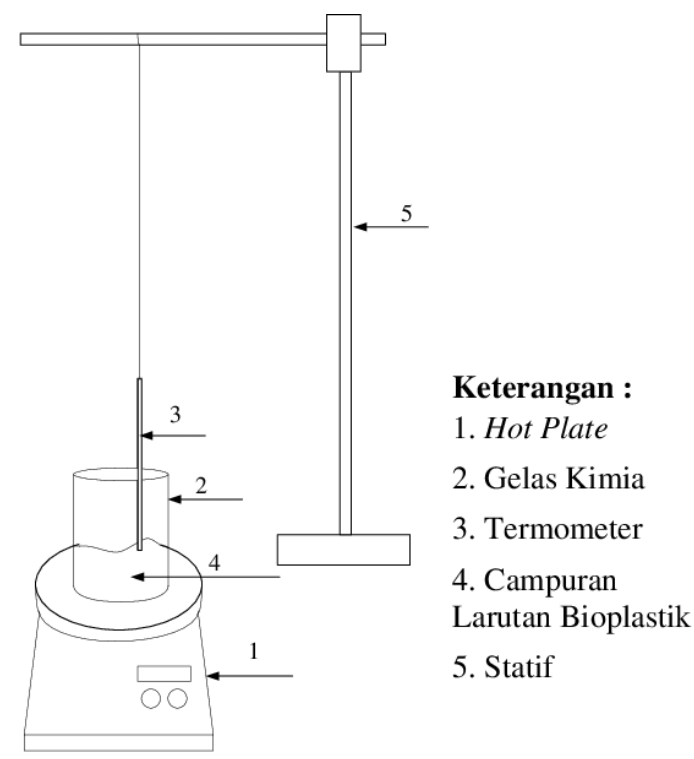

Fig 1. Activated Carbon Activation Tool

\section{Carbonization Process}

The prepared cassava peel was then carbonized at $300^{\circ} \mathrm{C}$ for 2 hours in a furnace, then carbon was formed and then cooled in a desiccator. The cooled carbon is then pulverized and filtered using an 80 mesh sieve, and carbon is formed in powder form.

\section{Activation Process}

Make a solution of $\mathrm{NaOH}$ activator with a concentration of $0.1 \mathrm{~N} ; 0.2 \mathrm{~N} ; 0.3 \mathrm{~N} ; 0.4 \mathrm{~N}$; and $0.5 \mathrm{~N}$. Weigh 10 grams of carbon that has passed 80 mesh and soak the carbon into the activator solution with stirring using a magnetic stirrer and heated at $80^{\circ} \mathrm{C}$ for 1 hour.

Neutralization and washing process

Activated carbon is washed using distilled water until the $\mathrm{pH}$ is neutral. Then the activated carbon was dried in the oven until the weight was constant. 
Effect of Sodium Hydroxide Concentration on Production of Activated Carbon from Cassava Peel

Mitha Puspitasari, Wibiana Wulan Nandari, Sri Wahyuni Santi $R$

\section{Ash Level Test}

2 grams of activated carbon is placed into a crucible that has been dried and weighed and then put in a furnace at a temperature of $700{ }^{\circ} \mathrm{C}$ for 6 hours or until all activated carbon becomes ash.

\section{Moisture Test}

1 gram of activated carbon was placed in a porcelain dish that had been dried and weighed and then placed in an oven at $110{ }^{\circ} \mathrm{C}$ for 1 hour. The results obtained are then cooled in a desiccator and weighed.

Surface area analysis with BET analisa analysis

\section{FINDING AND DISCUSSION}

\section{Water Content}

Water content testing is carried out to determine the water content contained in activated carbon after carbonization. The resulting water content is a measure of the ability of the activator as a dehydrating agent. Figure 1 . shows the effect of the concentration of the $\mathrm{NaOH}$ activator used on the percentage value of the water content of activated carbon from cassava peel waste with a size of $-80,+100$ mesh.



Fig 2 . Graph of Relationship between Water Content and Concentration of $\mathrm{NaOH}$

Based on the water content test that has been carried out, the highest water content is at the $0.5 \mathrm{~N}$ $\mathrm{NaOH}$ activator concentration, which is $9.3406 \%$. Based on Figure 2, it can be seen that the water content of activated carbon in various variables has met the quality standard of SNI 06-3730-1995 for a maximum water content of $15 \%$. Figure 2 also shows that the water content increases along with the increase in the concentration of the activating agent, where for the water content of the $0.1 \mathrm{~N} \mathrm{NaOH}$ activator is $8.6316 \%$, the water content of the $0.2 \mathrm{~N} \mathrm{NaOH}$ activator is $9.0642 \%$, the water content of the $\mathrm{NaOH}$ activator is $9.0642 \% .0 .3 \mathrm{~N}$ is $9.1186 \%$, the water content of $0.4 \mathrm{~N} \mathrm{NaOH}$ activator is $9.2988 \%$, and the water content of $0.5 \mathrm{~N} \mathrm{NaOH}$ activator is $9.3406 \%$. This is because the more concentrated the concentration of the activating agent, the more optimal the process of dissolving the remaining carbonization and organic minerals on the surface of the charcoal, so that the resulting pores will be more and more. This increased number of pores also increases the nature of activated carbon to absorb water from the air (hygroscopic properties) (Subrada et al, 2005). 


\section{Ash Level}

Ash content indicates the amount of materials and minerals that cannot be burned during the carbonization process (Siahaan, et al. 2013). According to Siregar (2015), stated that activated carbon from the basic ingredients of natural resources does not only contain carbon compounds, but also contains several minerals. Figure 1. shows the effect of the concentration of $\mathrm{NaOH}$ activator used on the percentage value of activated carbon ash content from cassava peel waste with a size of $-80,+100$ mesh.

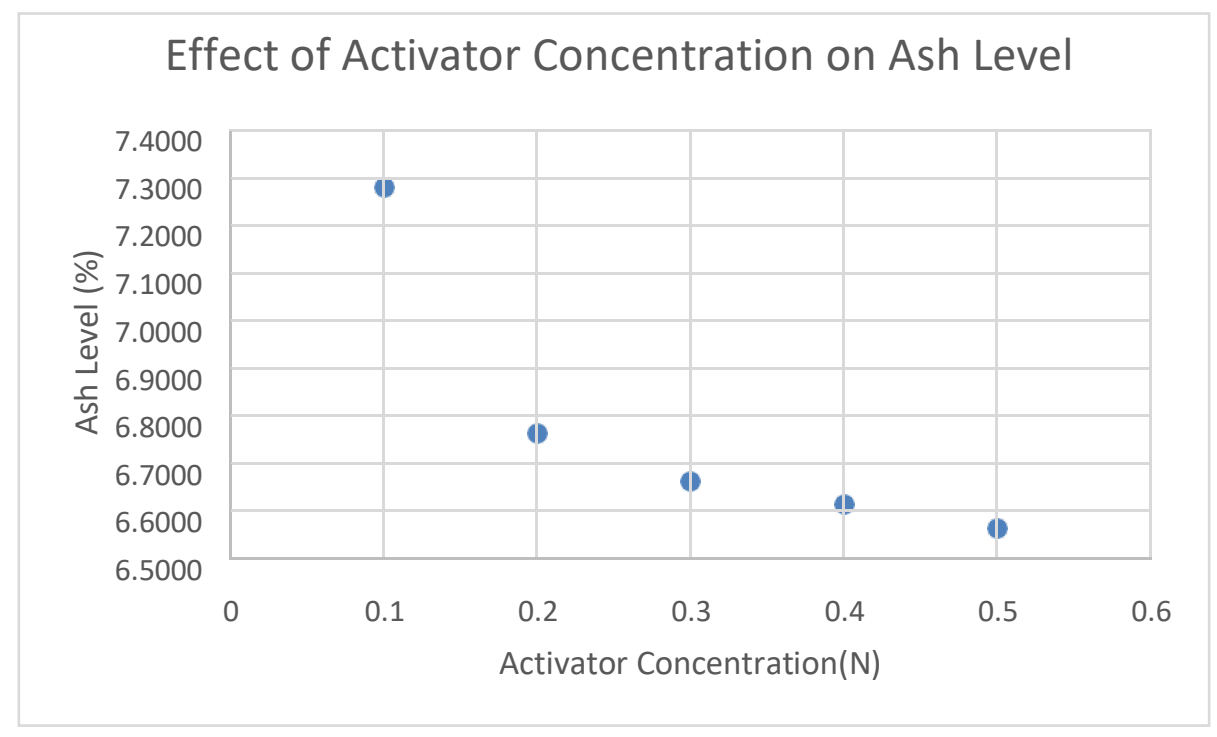

Fig 3. Graph of Relationship between Ash Content and Concentration of $\mathrm{NaOH}$

Based on the ash content test that has been carried out, it produces the highest ash content at $0.1 \mathrm{~N} \mathrm{NaOH}$ activator concentration, which is $7.3050 \%$. Based on Figure 3.1, it can be seen that the ash content of activated carbon in various variables has met the quality standard of SNI 06$3730-1995$ for a maximum ash content of $10 \%$. Figure 3.1 also shows that the ash content decreases along with the increase in the concentration of the activating agent, where the ash content in the $0.1 \mathrm{~N} \mathrm{NaOH}$ activator is $7.3050 \%$, the ash content of the $0.2 \mathrm{~N} \mathrm{NaOH}$ activator is $6.7891 \%$, the ash content of the $\mathrm{NaOH}$ activator is $6.7891 \% .0 .3 \mathrm{~N}$ is $6.6894 \%$, the ash content of $0.4 \mathrm{~N} \mathrm{NaOH}$ activator is $6.6396 \%$, and the ash content of $0.5 \mathrm{~N} \mathrm{NaOH}$ activator is $6.5907 \%$. Basically, the more concentrated the solution of the activating agent used, the more the surface area of the activated charcoal will be expanded because the pores produced are more and more. In the formation of pores, during the heating process there is a burning process on the surface of the activated carbon which produces ash, so that the more pores produced, the higher the ash content produced (Subadra, 2005). The activation process using $\mathrm{NaOH}$ is able to degrade mineral content that can clog the pores of the activated carbon so that the surface of the activated carbon is reduced.

\section{Iodine Number Test}

Testing the quality of absorption of iodine on activated carbon aims to determine the adsorption ability of colored solutions. The absorption of activated carbon to iodine is the number of milligrams of iodine adsorbed by one activated carbon salt. Figure 1 . shows the effect of the concentration of $\mathrm{NaOH}$ activator used on the percentage value of the absorption of iodine on activated carbon from cassava peel waste with a size of $-80,+100$ mesh. 


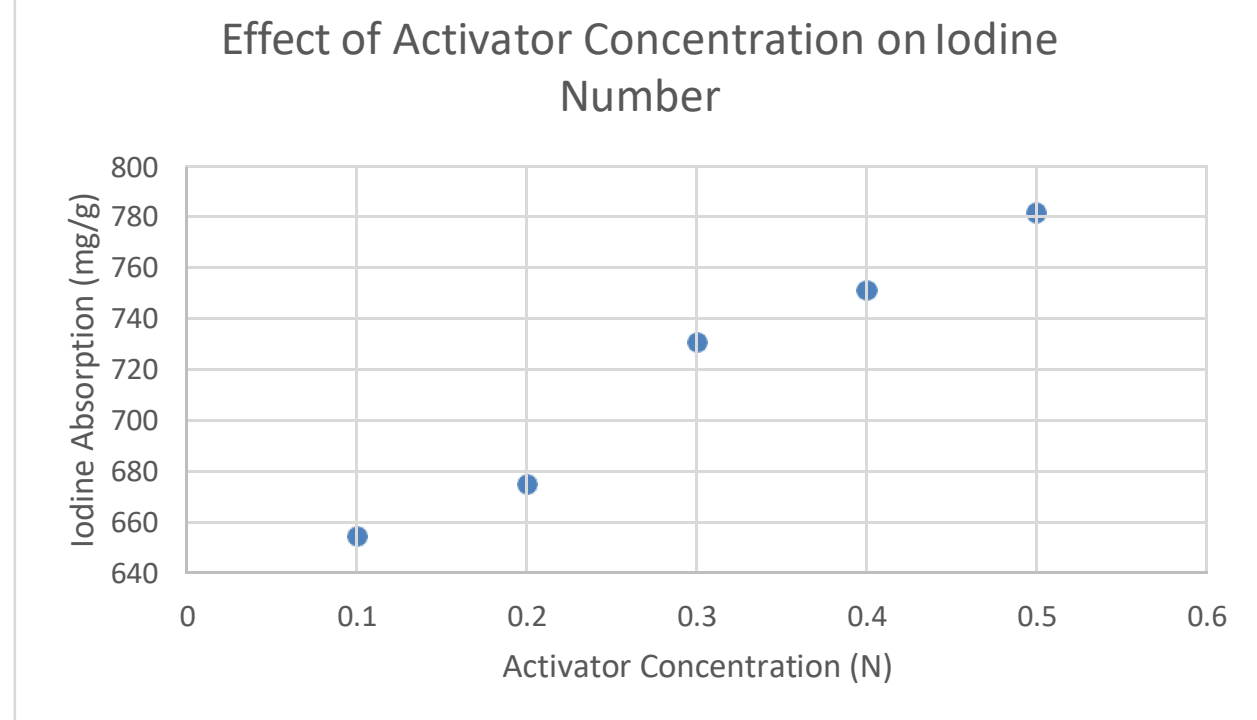

Fig 4. Graph of the relationship between Iodine Absorption and Activator Concentration

Based on the results of the iodine absorption analysis that has been carried out, it shows that the activated carbon with the best iodine absorption is carbon with an activator concentration of $0.5 \mathrm{~N}$, which is $781.7656 \mathrm{mg} / \mathrm{g}$ carbon. Based on Figure 4, it can be seen that the absorption of iodine on activated carbon in various variables has met the SII quality standard no. 0258-79 From the overall results of the analysis, the absorption of iodine obtained in this study has complied with SNI 06$3703-1995$, which is at least $750 \mathrm{mg} / \mathrm{g}$. Figure 3.4 shows that the increase in activator concentration also increases the absorption of iodine, where the value of iodine absorption at $0.1 \mathrm{~N} \mathrm{NaOH}$ activator concentration is $654.8556 \mathrm{mg} / \mathrm{g}, 0.2 \mathrm{~N} \mathrm{NaOH}$ activator concentration is $675.1612 \mathrm{mg} / \mathrm{g}$, activator concentration $\mathrm{NaOH} 0.3 \mathrm{~N}$ was $731.0016 \mathrm{mg} / \mathrm{g}$, the concentration of $\mathrm{NaOH}$ activator $0.4 \mathrm{~N}$ was $751.3072 \mathrm{mg} / \mathrm{g}$, and the concentration of $\mathrm{NaOH}$ activator $0.5 \mathrm{~N}$ was $781.7656 \mathrm{mg} / \mathrm{g}$. This is because as the concentration of activator increases, more pores are formed so that the absorption of activated carbon also increases.

\section{CONCLUSION AND FURTHER RESEARCH}

Based on the research and discussion that has been carried out, the activated carbon produced has met the quality standard of SNI 06-3730-1995, with the following characteristics:

- Moisture content 8.6316 - 9.3406\%, maximum 15\%

- Ash content $6.5907-7.3050 \%$, maximum $10 \%$

-Iodine Number 654.8556 - $781.7656 \mathrm{mg} / \mathrm{g}$, minimum $760 \mathrm{mg} / \mathrm{g}$

\section{REFERENCES}

Ariyani, Ariyani, et al. "Pemanfaatan kulit singkong sebagai bahan baku arang aktif dengan variasi konsentrasi NaOH dan suhu." Konversi 6.1 (2017): 7-11.

Atkins, P.W., (1999), Kimia Fisika Jilid II, Erlangga, Jakarta.

Badan Pusat Statistik, “Pertumbuhan Ekonomi Indonesia Triwulan IV-2019,” Www.Bps.Go.Id, 2020.

Bhatnagar, A., W. Hogland, M. Marques, and M. Sillanpaa. 2013. An Overview of The Modification Methods of Activated Carbon for Its Water Treatment Applications. Chemical Engineering Journal. 219: 499-511. 
Budiono, Ari, dkk. 2007. Pengaruh Aktivasi Arang Tempurung Kelapa Dengan Asam Sulfat dan Asam Fosfat Untuk Adsorpsi Fenol. Universitas Diponegoro.

Dewi, A.M., Pranoto, Y., \& Barati. 2017. Ekstraksi dan Karakterisasi Selulosa dari Limbah Ampas Sagu. Prosiding SNST ke8 Tahun 2017. 6-9 Oktober, Semarang.

Djatmiko dan Prowiro (1970), Pembuatan Arang Aktif, Lembaga Ilmu Pengetahuan Indonesia, Bandung.

E. A. Saputro, V. Dwi, R. Wulan, B. Y. Winata, R. Ramadhan, and N. K. Erliyanti, "Review article The Process of Activated Carbon from Coconut Shells Through Chemical Activation," vol. 09, no. April, 2020, doi: 10.22487/25411969.2019.v9.i1.15042.

Giyatmi, 2008, Penurunan Kadar Cu,Cr dan Ag Dalam Limbah Cair Industri Perak di Kotagede Setelah Diadsorpsi Dengan Tanah Liat Dari Daerah Godean, Yogyakarta: Seminar Nasional SDM Teknologi Nuklir

Hassler, J.W., Actived Carbon, Chemichal Publishing Co. Inc., New York, 1951.

Idrus, R., Lapanporo, B.P., \& Putra Y.S. (2013). Pengaruh Suhu Aktivasi Terhadap Kualitas Karbon Aktif Berbahan Dasar Tempurung Kelapa. Prisma Fisika, 1(1), 50-55.

Jankowska, H. 1991. Active Carbon. Ellis Warwood. Polland.

Kinoshita, K. 1988. Carbon Electrochemical and Physcochemical Properties. New York : John Wiley \& Sons

Krisnadwi. 2014. Istilah Kimia Umum. Kimia FMIPA, Bandung.

Kristianto, H. 2017. Review: Sintesis Karbon Aktif dengan Menggunakan Aktivasi Kimia ZnCl2.

Jurnal Integrasi Proses. 6(3): 104-111.

M. Aryanti, "Penjernihan Air Sungai Lahan Gambut Menggunakan Karbon Aktif Gambut," Univ. Indones., no. 416, p. 76277, 2010.

Manocha, S.M. 2003. Porous Carbons. Sadhana 28 : 335-348.

Maulinda, Leni, Z. A. Nasrul, and Dara Nurfika Sari. "Pemanfaatan kulit singkong sebagai bahan baku karbon aktif." Jurnal Teknologi Kimia Unimal 4.2 (2017): 11-19.

McCabe, Warren L \& Smith, J.C. 1999. “Operasi Teknik Kimia”. Alih Bahasa Jasiji, E.Ir. Edisi ke-4.

Penerbit Erlangga : Jakarta.

Meilita Tryana Sembiring, ST, Tuti Sarma Sinaga, ST,2003. Arang Aktif Pengenalan dan Proses Pembuatannya. Fakultas Teknik Universitas Sumatera Utara.

Mutiara, T.; Fajri, R.; Nurjannah, I., Karakterisasi Karbon Aktif dari Serbuk Kayunangka Limbah Industri Penggergajian dan Evaluasi Kapasitas Penyerapan dengan Methylene Blue Number, 2016, Tenoin, 22(6), 452-460.

Permatasari, A. R., L. U. Khasanah, dan E. Widowati. 2014. Karakterisasi Karbon Aktif Kulit Singkong (Manihot utilissima) dengan Variasi Jenis Aktivator. Jurnal Teknologi Hasil Pertanian. 7(2): 70-75.

Pujiyanto. 2010. "Pembuatan Karbon Aktif Super dari Batubara dan Tempurung Kelapa”.

Fakultas Teknik, Program Studi Teknik Kimia, Universitas Indonesia. Depok.

Raharjo, S. 1997. Pembuatan Karbon Aktif dari Serbuk Gergajian Pohon Jati dengan NaCl sebagai Bahan Pengaktif. Skripsi Tidak Diterbitkan. Malang: Jurusan Kimia Fakultas Matematika dan Ilmu Pengetahuan Alam. Universitas Brawijaya.

RAHMAT, R., 1997, Usaha Tani Jagung, Penerbit Kanisius, Jogjakarta.

Salim, E. (2011). Mengolah Singkong Menjadi Tepung Mocaf. Yogyakarta: Andi Offset.

Santoso, Rendi Hadi, and Wahyunanto Agung Nugroho. "Pembuatan dan Karakterisasi Karbon Aktif dari Kulit Singkong (Manihot esculenta Crantz) Menggunakan Activating Agent KOH." Jurnal Keteknikan Pertanian Tropis dan Biosistem 2.3 (2014).

Sembiring, M., dan Sinaga, T., "Arang Aktif", Jurusan Teknik Industri, Fakultas Teknik, Universitas Sumatera Utara, 2003.

Smisek, M. \& Cerny S. 1970. Active Carbon Manufactute Properties and Aplication. Amsterdam: El Savier Publishing Company. Hal 10-25. 
Effect of Sodium Hydroxide Concentration on Production of Activated Carbon from Cassava Peel Mitha Puspitasari, Wibiana Wulan Nandari, Sri Wahyuni Santi $R$

SOEHARDI, S., 2004, Memelihara Kesehatan Jasmani Melalui Makanan, ITB, Bandung.

Subadra, I. Setiaji, B. dan Tahir, I. 2005. Activated Carbon Production From Coconut Shell With (NH4)HCO3 Activator As An Adsorbent In Virgin Coconut Oil Purification. Yogyakarta: Universitas Gadjah Mada.

Sudibandriyo, M. dan Lydia. 2011. Karakteristik Luas Permukaan Karbon Aktif Dari Ampas Tebu Dengan Aktivasi Kimia. Jurnal Teknik Kimia Indonesia Vol. 10, No. 3, 2011, 149 -

156. Depok

Sudirjo, M. 2006. Pembuatan Karbon Aktif dari Kulit Kacang Tanah (Arachis Hypogeae) dengan Aktivator Asam Sulfat.Tugas Akhir Universitas Diponegoro.

Sugiharto. 1987. Dasar-Dasar Pengolahan Air Limbah. UI Press. Jakarta. Sukardjo.2002. Kimia Fisika. cetakan ketiga. Rineka cipta, Jakarta

Swiatkowski, A. 1998, Adsorption and its Aplication in Industry and Environmental Protection Studies in Surface Science and Catalysis. Belanda: Elsivier

Teng H. and Hsu, L. Y. 1999. High Porosity Carbon Prepared from Bituminous Coal with Potassium Hydroxide Activation. J. of Ind Eng Chem. Res., 38 (8): 2947-2953

Yahya, M.A. (2018, Jun). "A Brief Review on Activated Carbon Derived From Agriculture ByProduct." Recent Advancement on Applied Physic Industrial Chemistry and Chemical Technology, pp. $1-8$

Annex 1. Proof of submission at the LPPM UPNVY International Seminar

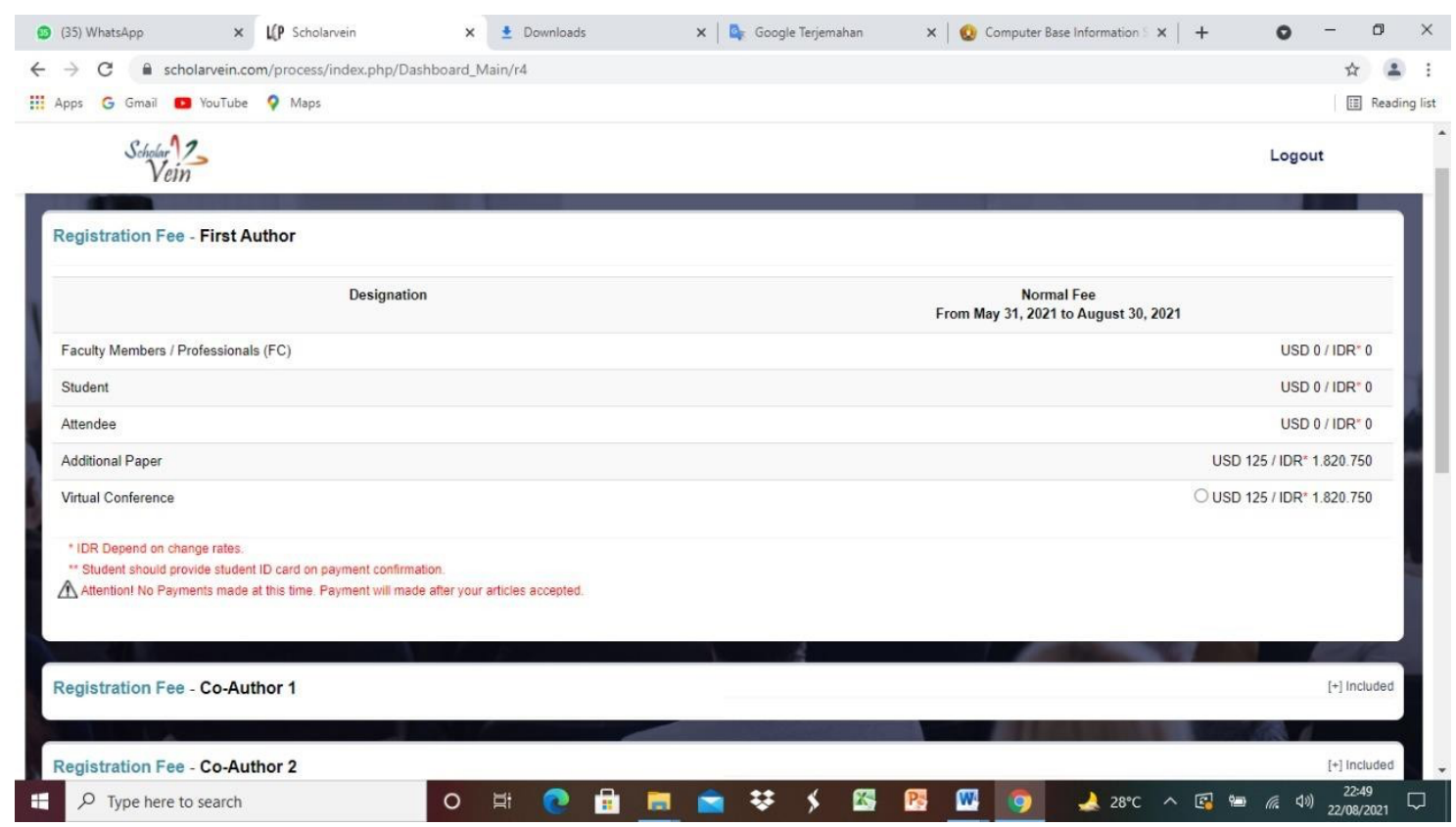

